\title{
Review on Adoption of Improved Agricultural Technologies in Ethiopia
}

\author{
Alemayehu Keba \\ Department of Agricultural Economics and Agribusiness Management, College of Agriculture and Veterinary Medicine, Jimma University, \\ Jimma, Ethiopia
}

Email address:

alemayehukeba@gmail.com

\section{To cite this article:}

Alemayehu Keba. Review on Adoption of Improved Agricultural Technologies in Ethiopia. International Journal of Health Economics and Policy. Vol. 4, No. 1, 2019, pp. 11-19. doi: 10.11648/j.hep.20190401.12

Received: November 26, 2018; Accepted: January 17, 2019; Published: March 15, 2019

\begin{abstract}
The objective of this review was to assess the factors affecting adoption and intensity of agricultural new technologies. The adoptions of agricultural technologies were highly influenced by socio-economic factors, institutional, location factors as well as agro-ecological factors and the characteristics of the farmers were those factors affecting the adoption and intensity of agricultural new technologies. Also the review was focused on the probability of adoption of crop, feed improvement technologies and artificial insemination. The other objective of the review was the impact of the technology adoption on the small holder farmers' welfare.
\end{abstract}

Keywords: Adoption, Impact, Intensity and Welfare

\section{Introduction}

\subsection{Background and Justification of Seminar}

Agriculture is the provider of basic human need, nutrition is the world's largest user of land, occupying more than one third of Earth's terrestrial surface and using vast amounts of water. It affects our daily life in many ways, both directly and indirectly. Humans expect agriculture to supply sufficient nutrients, economically and culturally valued foods, fibers and other products. Agriculture is important for inclusive development because it produces food as well as economic wealth for many of the world's poorest people that allows for improved livelihoods through better health care, education, infrastructure improvements and greater investment in environmentally sound practices. For Sub Saharan Africa, growth generated by agriculture is eleven times more effective in reducing poverty than GDP growth in any other sectors [23].

Different studies have been conducted on adoption of agricultural technologies in Ethiopia. However, many of them focus on a single commodity or technology, and do not consider the possible inter-relationships between the various practices and intensity of adoption of a package of technologies [3, 22].

From the beginning, CASCAPE has adopted a bottom-up planning process involving farmers, extension agents and researchers to identify the needs, priorities and interests of target farmers [26].

According to Tewodros and his team study shows, the drivers of technology adoption broadly include factors that positively promote technology adoption. Drivers can be internal (based on the decision maker's personal characteristics) or external (policy related). Inhibitors are factors that de-motivate or discourage technology adoption. Likewise, inhibitors can be either internal or/and external factors. The assumption behind scaling of best practices in AGP is that model farmers have those characteristics that drive them to adopt technologies and improved practices. Understanding what makes the group of model farmers more successful than the so-called non-model farmers should make clear those crucial drivers and inhibitors that need to be recognized so that non-model farmers can also become better achievers in the agricultural sector [45].

The selection of model and non-model farmers has not been done by CASCAPE, but by the extension system and For this study, authors have adopted the official classification (MoA) that the regional bureaus of agriculture (BoA) and the woreda offices of agriculture (WoA) have put in place [45].

Despite the improvements made over the last four decades in the agricultural sector, a combination of declining soil 
fertility, population growth, low uptake of external inputs, and climate disruption has resulted in a dramatic fall in per capita food production [33]. To increase the production level of agriculture sector, we need to enhance the adoption of new technologies. However, in Ethiopia the practice is still limited due to different factors. Different studies have been conducted on adoption of agricultural technologies in Ethiopia [43].

The rate of technology adoption and its intensity in the country is very low even by sub-Saharan standard. For instance, the average adoption rate of modern fertilizer is estimated to be less than $33 \%$ of the total cultivated land and the average level of use of modern fertilizer is only $11 \mathrm{~kg}$ per hectare which is very low compared to $48 \mathrm{~kg}$ per hectare in Kenya. In addition, the loss of soil nutrients due to land degradation and improper use of animal dung is the highest in sub-Saharan Africa [19].

\subsection{Statement of Problem}

In spite of the widespread technology generation and dissemination efforts; however, yields of major crops such as wheat, maize and teff are still low averaging 2.45 ton/ha, $3.25 \mathrm{ton} / \mathrm{ha}$, and $1.47 \mathrm{ton} / \mathrm{ha}$, respectively, suggesting the country has not fully taped the benefits of the investments made on agricultural technology generation and dissemination efforts [15]. The low crop productivity in one hand and availability of proven improved agricultural technologies that would increase productivity by a significant margin as well as the extensive extension efforts to get farmers adopt improved agricultural technologies on the other hand has triggered interest in crop technology adoption and analysis of factors that influence the adoption decision behavior of smallholder farmers in the country [13].

Smallholder farmers' knowledge and use of agricultural technologies in general and improved maize varieties in particular, are restricted due to various factors that are either internal or external to the farmers' circumstances. Most commonly studied internal factors that affect adoption and use of agricultural technologies are farmers' attitude towards risk [20], household characteristics that affects the level of production and consumption, resource endowments, etc. External factors could be access to technologies, in particular through a well-developed seed system [4, 6, 14].

There have been few studies conducted to determine the rate of adoption of improved agricultural technologies in Ethiopia. However, to the knowledge of the authors, very limited analysis has been done of factors influencing the intensity or extent of utilization of the technologies once they are introduced. The existing domain of research and development endeavors' so far seem to be unable to provide adequate empirical explanation as to why small-holders in Ethiopia usually fail to adopt the desired level of recommended technologies.

\subsection{Objective}

\subsubsection{General Objective}

To review the adoption improved agricultural technologies in Ethiopia.

\subsubsection{Specific Objective}

To review the factors that affect adoption and intensity of improved agricultural technology.

To review impact of adoption of improved agricultural technologies on small holder farmers' welfare.

\subsection{Significance of the Study}

The study focuses on the analysis of socio-economic factors that influence the adoption of improved agricultural technologies and its extent among farmers and impact of improved agricultural new technologies on small holder farmers' welfare. Generally, the objectives of this review is important to identify factors that influence the adoption of new improved agricultural and determine the extent to which the farmers are aware of the improved agricultural technologies, the influence of socio-economic characteristics of the farmers on adoption of improved agricultural and to identify the problems confronting farmers' adoption of improved agricultural technologies and also the impact of improved agricultural new technologies on small holder farmers in Ethiopia.

\section{Literature Review}

\subsection{Definitions and Concepts}

Adoption is a process consists of three stages namely preadoption, adoption and post- adoption. At the pre-adoption stage, people may examine a new technology and consider adopting it. At the adoption stage, they form an intention to adopt the technology, and they eventually purchase and use it. At the post-adoption stage, people can either continue or discontinue using the technology. It is well recognized that improvement in agricultural productivity among farmers is achieved through improved agricultural technologies [31].

The Adoption process is the change that takes place within individuals with regard to an innovation from the moment that they first become aware of the innovation to the final decision to either use it or not. Also adoption does not necessarily follow the suggested stages from awareness to adoption; trial may not always be practiced by farmers to adopt new technology, they may adopt the new technology by passing the trial stage. The adoption pattern for a technological change in agriculture is a comprehensive process. A large number of personal, situational and social characteristics of farmers have been found to be related to their adoption rate [35].

\subsection{Adoption of Improved Agricultural Technology}

Agricultural new technologies constitute the introduction and use of hybrids, the greenhouse technology, genetically modified food, chemical fertilizers, insecticides, tractors and the application of other scientific knowledge [28].

Most other studies also mention that technology adoption has a direct role on improving rural household welfare 
through increasing agricultural productivity [6].

The adoption intensity of crop technology packages in the 2013 season, farmers applied $71 \%$ of the potato technology package, $66 \%$ of the wheat technology package, $60 \%$ of maize technology package, $52 \%$ of the teff technology package, $46 \%$ of the barley technology package and $29 \%$ of the sorghum technology package. Region wise, crop technology packages adoption show the highest intensity in Amhara, followed by SNNP, Oromia and Tigray regions. The overwhelming number of farmers in all studied regions responded that seed unavailability was the first major inhibitor for use of improved seeds of cereal crops. The major reason cited by farmers for not adopting row planting technology included the labour demanding nature of the practice. The major inhibitors of pesticide use identified by farmers included high cost and unavailability. In most study regions, famers practiced hand weeding instead of herbicide [45].

According to Tewodros and his team study result shows between 27 and $55 \%$ of farmers used improved dairy breed and feed technologies with the lowest percentage in Oromia and the highest in Tigray. The use intensity of dairy cows was on average very low, ranging between 2 and $15 \%$. Similarly, use of artificial insemination was also low, between 12 and 24\%, 24, 12, 16 and 17 cows per hundred, in Tigray, Oromia, Amhara and SNNP regions, respectively. Only one third of the farmers used the full package for dairy, while the remaining farmers practiced the package partially. In the case of poultry, use of improved breeds was between 15 and 38\% [45].

Researchers have argued that numerous factors can affect the decision to adopt a technology or packages of technology [49].

The factors related to the characteristics of producers include education level, experience with the activity, age, gender, level of wealth, farm size, plot characteristics, labour availability, resource endowment, risk aversion, etc. The factors related to the characteristics and performance of the technology and practices include food and cash generation functions of the product, the perception by individuals of the characteristics, complexity and performance of the innovation, its availability and that of complementary inputs, the relative profitability of its adoption compared to substitute technologies, the period of recovery of investment, local adoption patterns of the technology, the susceptibility of the technology to environmental hazards, etc. The institutional factors include availability of credit, the availability and quality of information on the technologies, accessibility of markets for products and inputs factors, the land tenure system, and the availability of adequate infrastructure, extension support, etc. Enabling policies and programs, market linkages, access to institutional support and credit were found to play a positive role in stimulating farmer investment in and adoption of sustainable technologies [38].

\subsection{Crop Technology Adoption}

Realizing the drawbacks of the previous crop related technology adoption studies and prompted by recent intensified technology transfer efforts, the Ethiopian Institute of Agricultural Research (EIAR) partnering with several international agricultural research Centers conducted adoption studies at national level focusing on three cereals crops (maize, wheat and barley), three cool season legumes (lentil, chickpea and faba bean) and one root crop (potato) under the auspice of the project "diffusion of improved varieties in Africa (DIVA)" in 2011 [9-12, 46, 48]. Besides the DIVA study, several assessments were conducted on wheat, maize and tef aimed at updating varietal use by smallholder farmers.

\subsubsection{Adoption of Improved Maize Technologies}

Is the most widely cultivated cereal after teff in terms of area but is produced by more farms than any other crop (close to 8.8 million farming households). It accounts for the largest share of production by volume at $25.8 \%$. Maize is grown chiefly between elevations of 1500 and 2200 masl and requires large amounts of rainfall. Suitable temperature for maize is in the range of $19-30^{\circ} \mathrm{C}$. As to the soil type, clay loam is preferred for maize production. In addition to food grain, maize residues are also used as fodder, fencing materials, and cooking fuel [45].

Farmer responses suggest that $55.9 \%$ of the respondent used improved maize varieties during 2013 production season, the DNA fingerprinting indicated $61.4 \%$ of the respondents to have actually used improved maize varieties with a difference of 5.5 percentage points suggesting household survey based adoption estimates under estimate adoption levels. The same study further revealed that only $30 \%$ of the farmers know the variety they cultivated by name. When considering only adopters, the proportion of famers who identified the variety they grew by name increased to about $49 \%$. Farmer knowledge of cultivars, however, are restricted to only four hybrid maize varieties, namely, BH-660, BH-540, BH-140 and Shone [9].

\subsubsection{Adoption of Improved Wheat Technologies}

Account for a similar share of national cereal production as sorghum with $17 \%$ of planted area and $19 \%$ of production. Bread wheat is the most widely grown variety throughout the highlands and mid altitude areas. Wheat production typically takes place at altitudes of 1,600-3,200 masl in areas with average annual rainfall of $400-1,200 \mathrm{~mm}$ and average annual temperatures of $15-25^{\circ} \mathrm{C}$ [45].

Improved wheat seeds recycled at most for not more than 5 seasons, estimated $63 \%$ of the sample households found to have adopted improved wheat varieties on $52.8 \%$ of the wheat area across the country. The same study indicated that seed recycling is common across the study areas mainly due to the absence of formal mechanisms for supplying new improved varieties and farmers' lack of awareness of recently released improved varieties. Hence, appropriate mechanisms need to be devised to bridge the gap between new variety release and seed multiplication on one hand, farmer awareness and adoption on the other hand. The results also show that farmers believe yields of improved wheat varieties 
increase dramatically when properly fertilized [8].

As many as $76 \%$ of sample farmers used inorganic fertilizer (DAP) at an average rate of $68 \mathrm{~kg} / \mathrm{ha}$, indicating the need to find ways to improve fertilizer use. Similarly, adoption estimates of improved wheat varieties based on the 2013 study of tracking wheat varietal adoption using DNA finger printing revealed a high divergence between farmer responses based estimates and DNA finger printing estimates. While farmer responses indicated that about $63 \%$ of the farmers used improved wheat varieties, the DNA finger printing suggested that about $96 \%$ of the respondents cultivated improved wheat varieties revealing the household survey underestimated the economic importance of improved varieties in the wheat sector by about 33 percentage points. The result based on famer responses, however, is comparable with previous varietal adoption studies conducted in Ethiopia. Furthermore, the DNA finger printing identified some 23 improved wheat varieties are cultivated by smallholder farmers in the pilot areas revealing the household survey underestimated not only the level of use but also the diversity of the wheat varieties currently under cultivation [9].

\subsubsection{Adoption of Improved Teff Technologies}

Teff is a preferred staple food and cash crop in much of the highlands of the country. Teff is grown by 6.63 million farming households and accounts for $24.3 \%$ of all cultivated land, more than any other single crop in the 2013/14 cropping season. Teff can be grown under a wide variety of agro-climatic conditions, including elevations, rainfall, temperature, and soil conditions. Its optimal growing conditions coincide with its traditional production areas: 1,800-2,100 meter above sea level (masl), average annual rainfall of 750-1,000 $\mathrm{mm}$, average annual temperature of 10 $27 \mathrm{oC}$ and under a range of soil types. Teff straw is a preferred feed for cattle [45].

\subsubsection{Adoption of Improved Food Legume Technologies}

Among the legumes, adoption studies concentrated on chickpea, lentil and faba bean [11, 12, 46, 48].

A national chick pea varietal adoption study based on household survey revealed that about $17.4 \%$ chickpea growers used improved chick pea varieties on about $19.4 \%$ of the chickpea acreage. Of the 9 most important chickpea growing zones included in the study, three zones namely North Shewa of Amhara region, East and West Shewa Zones of Oromia region has the highest holder and area weighted adoption rates of over $30 \%$. The study further indicated that data collected form expert panel and community focus group discussions (FGDs) provide good estimates of adoption and diffusion patterns of chickpea varieties. Adoption estimates from the panel of experts ,stands at $13.1 \%$ suggesting experts ${ }^{\text {ee }}$ belief that the use of improved chickpea varieties is not yet widespread. Likewise, the community-based estimates indicated that at national level, $13.9 \%$ of the households adopted improved varieties on $10.3 \%$ of the total national chickpea area. Hence, given reasonably good correspondence among the national estimates of adoption, in terms of area under the improved varieties derived from the expert panel and the household survey, using a panel of experts can provide a quicker, cheaper and reliable estimate. While the panel of experts did not attempt to estimate adoption rate, i.e., in terms of number of growers, the estimates obtained using the community FGD, though not very close to those from the sample household survey, can provide useful information if and when household surveys are not feasible [11].

Adoption of improved lentil varieties across the country is fairly low with $12 \%$ of lentil growers using improved varieties on about $15.6 \%$ of the lentil area, suggesting a lot remains to be done to raise both the number of households using improved varieties as well as intensity of area under improved varieties. In terms of efficacy of approaches, estimates from the expert panel, community and household survey correspond fairly well with $10.8 \%, 13.4$ and $15.6 \%$ of the area share of improved varieties, respectively; suggesting expert panel and community survey could be used to generate the desired information quickly and cheaply [12].

\subsection{Livestock Technology Adoption}

Livestock is a key component of the mixed farming system in Ethiopia. Since Ethiopia has the largest livestock population in Africa, development in this sector will have a significant contribution to the economic growth of the country. However, livestock production is practiced in the traditional way and as such its productivity is low compared to global records. Livestock activities constituted $22.1 \%$ and $10.2 \%$ of agricultural and aggregate national GDP in 2009, respectively, while livestock related activities (livestock specific value added plus livestock dependent activities of other sectors such as draft power) constituted $35.6 \%$ and $16.5 \%$ of agricultural and national GDP [30].

The major efforts towards dairy development in the two countries have been focused on generation and dissemination of dairy technologies, including improved breeds of dairy cows, improved forages and animal health interventions [41].

The adoption of livestock technologies was highly influenced by location factors as well as agro-ecological factors. The probability of adoption of breed and feed improvement technologies and artificial insemination was higher in midland and highland areas compared to the lowlands. Being a member of a cooperative, access to markets, access to irrigation, total land and livestock holding and contact with the extension service also positively influenced livestock technology adoption. For most livestock technologies, adoption rate was higher with higher household income. The further away a farm was located from an allweather road the lower livelihood of the farmer to adopt livestock technologies [45].

\subsubsection{Dairy Package Adoption}

Adoption could be defined as the proportion of farmers who owned either milking or pregranant crossbred dairy cows. Among the packages of dairy production technologies, ownership of crossbred cows is considered as the major 
component technology followed by forage, and feeds and nutrition technologies. Therefore, the first decision made by farmers regarding adoption of dairy technologies is whether or not to own crossbred dairy cows [2].

Mass media exposure, training on dairy farming and knowledge of the dairy farmers on dairy husbandry practices had positive and highly significant relationship with the adoption of improved dairy husbandry practices. Education status and experiences of the dairy farmers on dairy farming and participation of the dairy farmers in various dairy farming related organizations also had positive and significant relationship with the adoption of the improved dairy husbandry practices [27].

Training on improved livestock technologies creates its awareness and is expected to affect its adoption positively $[27,34]$.

\subsubsection{Poultry Adoption}

Improved chicken breeds adoption was higher than adoption of the rest technology package elements. Improved chicken breeds adoption in the highland agro-ecology was statistically higher than the adoption in the mid altitude and lowland agro-ecologies [18].

Sex of the household head significantly affects the exotic breed adoption decisions. Female headed households have $17.1 \%$ predicted probability to adopt exotic poultry breed this might be due to the fact that females in the area mainly found in home and take care of the chickens. Family size has also a significant effect on adoption. Households having higher family size have the probability to adopt the exotic breeds. Distance to roads and town have a significant and negative impact on the predicted probability of adoption of exotic poultry breeds. The reason is that, these factors are highly associated with access to information and market. Thus, farmers who have access to information and market are more likely to adopt exotic poultry breeds. Numbers of poultry sold in the market per year have also a significant effect on adoption of the exotic breeds. Every increase in the number of poultry sold increases the predicted probability of adopting exotic breeds by $29.8 \%$. The use of additional packages is also one of the significant variables affecting adoption. It increases the predicted probability of adopting exotic poultry breeds by $55.4 \%$. This is because the use of additional packages such as improved feeding, housing, vaccination and medication improves the survival as well as reproductive performances of exotic poultry breeds. Access to training has also a significant impact on the probability of adopting exotic breeds. Those farmers who have accessed training are more likely to adopt the breeds the reason is that training increases the knowledge of producers which in turn helps them to undertake informed decisions [39].

\subsubsection{Modern Beehive Adoption}

The main determinants of modern beehive adoption in Arsi zone, Ethiopia are farmyard size, number of local beehives beekeepers possessed, training provided participation on demonstration, wealth status of beekeepers and participation of beekeepers on nonfarm income sources. Moreover, chemical application, bee predators, lack of knowledge and skill on modern beehives, lack of modern beehive accessories, lack of bee forage and lack of capital were the major beekeeping bottlenecks [42].

Beekeeping requires protective clothes (over all suit, bee veil and glove) and equipments like smoker to operate the hive with honey bee colony. The availability of the above materials influences the adoption of the technology [47].

\subsection{Factors Affecting Adoption and Intensity of Agricultural New Technologies in Ethiopia}

Technology adoption in developing countries reveals that the various factors that influence technology adoption can be grouped into the following three broad categories (1) factors related to the characteristics of producers i.e., the farmers; (2) factors related to the characteristics and relative performance of the technology and (3) program and institutional factors [49] and [44].

The factors related to the characteristics of producers include education level, experience with the activity, age, gender, level of wealth, farm size, plot characteristics, labor availability, resource endowment, risk aversion, etc. The factors related to the characteristics and performance of the technology and practices include food and cash generation functions of the product, the perception by individuals of the characteristics, complexity and performance of the innovation, its availability and that of complementary inputs, the relative profitability of its adoption compared to substitute technologies, the period of recovery of investment, local adoption patterns of the technology, the susceptibility of the technology to environmental hazards, etc. The institutional factors include availability of credit, the availability and quality of information on the technologies, accessibility of markets for products and inputs factors, the land tenure system, and the availability of adequate infrastructure, extension support, etc. Enabling policies and programs, market linkages, access to institutional support and credit were found to play a positive role in stimulating farmer investment in adoption of sustainable technologies [38].

\subsubsection{Demographic Factors}

Adoption intensity decreased when the age of the household head and the dependency ratio in the household increased. Which implied the need for sufficient labour and openness in learning about the technology as it is relatively better known among young farmers. Households with better access to irrigation showed a significantly higher rate of adoption, and the level of adoption was positively associated with distance to the nearest market and the household annual cash income. The irrigation and income factors reflected that the investment capacity of the household increased adoption [45].

\subsubsection{Socio-Economic Factors}

Education status of the household head is the most common and important variable that is found to explain farmers' agricultural technology adoption behavior. Various 
studies confirmed that it has a significant positive influence on adoption of technologies.

Household head's level of education was found to enhance awareness and decision-making, which was likely to increase the probability of adoption of SWC practices. Educated household heads may have enhanced practical awareness and understanding of an erosion problem and apply measures to control it rather than considering erosion as a curse. He strongly agrees that education has positive and significant relationship with the adoption of agricultural technology. This is due to education has the power to change the knowledge, skill and attitude of farmers. It also enhances the analytical and problem-solving skills of farmers. In addition, Education enhances a locative ability of decision makers by enabling them to think critically and use information sources efficiently [40].

Farmers with more education should be aware of more sources of information, and more efficient in evaluating and interpreting information about new agricultural technologies than those with less education. That is why agree those farmers who have better education status have higher probability to adopt agricultural new technology than those we do not have [37].

Many studies conducted in different parts of Ethiopia showed that farm land, livestock holding and access to different productive assets have been affecting food security status of rural households in Ethiopia. Availability and amount of family labor plays a vital role in determining adoption and intensity of use of agricultural technologies. The existence of active work force in rural households usually encourages them to show interest in trying some agricultural technologies. Off course, the influence of labor availability on adoption depends on the characteristics of the technology to be adopted. When the new technologies in relative to the older ones are more attractive and labor intensive, farmers with more labor would tend to adopt those technologies. Some new technologies are relatively labor saving and others are labor using. For example, when a technology is labor saving like tractors, harvesters, pesticides and the like, its impact will be negative. For those laborusing technologies, like improved varieties of seeds and fertilizer labor availability plays significant role in adoption. Plenty of adoption studies found out a positive impact of family labor on technology adoption. The higher family labors increase the probability to adopt agricultural new technologies. Most of Ethiopian farmers have not used labor saving technologies like tractors, harvesters in their production system. They depend on labor-using technologies and agricultural new technology requires human resource from sowing to the final harvesting of the crop. The impact of Farm size on adoption and intensity of use agricultural technologies on the other hand, is not consistently similar in various adoption studies [5].

Some of the studies showed a positive influence of the variable on adoption decision. For instance, studied determinants of adoption and intensity of use of improved Maize varieties in the Central Highlands of Ethiopia and found a significant positive effect. Similar, results by other researchers found a reverse effect of land size on the joint adoption of inorganic and improved maize varieties. It is reported that there is positive relationship of farm size with adoption. The reviewer supported the argument provided by those researchers' farm size has positive relationship with adoption of agricultural new technologies this is because most of Ethiopian farmers have grown different varieties of crops in turn requires larger farm size [32].

In addition, most of Ethiopian farmers involved in mixed farming (crop and animal production). According to Diiro off-farm income is expected to provide farmers with liquid capital for purchasing productivity enhancing inputs such as improved seed and fertilizers. In another study conducted by Ibrahim et al. annual income of the respondent had a significant positive relationship with the adoption of recommended technologies in Bangladesh i.e., the higher the annual income of the respondents, the more they adopted recommended technologies. The influence of annual gross income was robust in our analysis and statistically significant in the adoption of teff, maize, wheat, barley and sorghum technology package [17].

Hence, resource endowment of farmers and their income generating capacity is expected to have a positive impact on the likelihood of adoption of these technologies and practices [49].

\subsubsection{Institutional Factors}

Institutional factors deal with the extent or degree to which institutions impact on technology adoption by smallholders. Institutions include all the services to agricultural development, such as finance, insurance and information dissemination. They also include facilities and mechanisms that enhance farmers' access to productive inputs and product markets. Extension service is a very crucial institutional factor that differentiates adoption status among farmers. In the existing situation much of agricultural technology delivery is undertaken by the extension system. Access to participate in training, demonstration, field day and other extensions services therefore creates the platform for acquisition of the relevant information that promotes technology adoption. Several studies have used different variable to measure farmers' access to extension services. Organization membership is another factor influencing technology adoption. The cooperative membership has positive role on technology adoption by smallholder farmers in Ethiopia [1, 16].

Farmers who participated more in community-based organizations were likely to engage in social learning about the technology, hence raising their likelihood to adopt the technologies [25].

Market distance of the respondents is important for the producers to get attractive market price through reduction of transportation cost. The increase in market distance make farmers to get out-dates market information and becoming out of adopting agricultural new technologies [7].

The distance to market centers was negatively and 
significantly related to adoption of fertilizer [21].

Decreasing the distance from the market decreased the transportation cost of agricultural inputs. Hence market distance and use of inorganic fertilizer had a negative relationship [32].

Access to credit service is the source of finance for the medium and lower income households to buy inputs for agricultural production. In Ethiopia, the credit service given in kind and cash form especially credit services delivered for agricultural production system. Different Authors conformed that farmers who have access to credit service had more probability to adopt the agricultural new technologies than otherwise. Daniel and Kafle confirm access to credit can increase the probability of adoption of agricultural new technologies by offsetting the financial short fall of the households [24].

\subsection{Impact of Improved Agricultural New Technologies on Smallholder Farmers}

To identify the impact of the technology adoption on the sample households, in the study, outcome variables which are farm income \& consumption expenditures of the farm households surveyed were analyzed using the propensity Score match of the adopters and non-adopters of the technology. Propensity score matching has the advantage of reducing the dimensionality of matching to a single dimension. This is the best possible procedure to follow since the households in both adopters and non-adopters" samples might have similar or closer propensity scores even though they might be dissimilar on the basis of each covariate. Based on the fact above, once matching process is taken place, a comparable sample of control (non-adopters) is created which is similar to the adopters except the decision of adopting the technology. So the outcome variables average income and average consumption expenditures of these two new samples of adopters and non-adopters were compared using the nearest neighborhood matching method of ATT estimation without any significant biases. The procedure of calculating ATT based on propensity score match method is consistent with the Mendola who conducted a study on the potential impact of agricultural technology adoption on poverty alleviation strategies and found a positive effect of agricultural technology adoption on farm household wellbeing suggesting that there is a large scope for enhancing the role of agricultural technology in contributing to poverty alleviation [36].

Propensity score matching (PSM) procedure balances distributions of observed covariate between adopters of technology and non-adopters based on similarity of their predicted probabilities of adopting the technology (matching their propensity scores) [29].

\section{List of Abbreviations and Acronyms}

$\begin{array}{ll}\text { AGP } & \text { Agricultural Growth Program } \\ \text { AI } & \text { Artificial Insemination } \\ \text { BoA } & \text { Bureaus of Agriculture }\end{array}$

\section{Conclusions and Recommendations}

\subsection{Conclusion}

Agricultural technology adoption is an essential strategy for increasing agricultural productivity, achieving food selfsufficiency and alleviating poverty and food insecurity among smallholder farmers in Ethiopia. In Ethiopia, farmers have been adopting and using different agricultural technologies, the adoption rate of the technologies has not at good level when compared with another country. The variables significantly affect the adoption of agricultural new technologies by farmers are age, availability of training, education level, family size, farm size, extension service provision, saving institution factor, providing participation of demonstration and credit access.

\subsection{Recommendation}

To solve problems of inadequate use of production technologies, decision makers have pursued a range of policies and strategies to boost agricultural production and productivity.

To solve problems encounter for adoption of technology the decision makers (Researchers) and policy makers (Government, MoA, Regional Agricultural office, and NGO) should form inter-relationships between the various practices and intensity of adoption of a package of technologies rather than a single commodity or technology.

To encourage the participation of farmer to new technology the policy maker should provide excesses credit service, training and invite to participate to field demonstration.

The Government, MoA, Regional Agricultural office, Zonal and woreda's Agricultural office, NGO, Researchers and scholars are needed to further promote agricultural new technologies by designing based on farmer's problem and need.

\section{Acknowledgements}

I wish to acknowledge the Ethiopian Institute of Agricultural Research and the entire staff of the Department of Agricultural Economics and Agribusiness and Value Chain Management of Jimma University of Agriculture for the great support they offered during this review development by approving my seminar title on time. Moreover, special thanks to my coordinator Mr. Alemayehu Oljira and my class mate students for their boundless support and all those who contributed in one way or another to the success of this work. 
CASCAPE Capacity building for Scaling up of evidence-based best Practices in agricultural Production in Ethiopia project

DA Development Agent

DAP Di-Ammonium Phosphate

DIVA Diffusion of Improved Varieties In Africa

DNA Deoxyribonucleic Acid

EIAR Ethiopian Institute of Agricultural Research

FDRE Federal Democratic Republic of Ethiopia

FGDs Focus Group Discussions

GDP Growth Domestic Product

MoA Ministry of Agriculture

SNNP Southern Nation Nationality and People

SWC Soil and Water Conservation

WoA Woreda Offices of Agriculture

\section{References}

[1] Abebaw, D., Haile, M. G. (2013) The impact of cooperatives on agricultural technology adoption: Empirical evidence from Ethiopia. Food Policy 38: 82-91.

[2] Agajie Tesfaye Tadele Mamo Tesfaye Solomon Yared Deribe Wudineh Getahun Tolesa Alemu Diriba Hunde Tamirat Fikadu Seyoum Bediye, 2016 Adoption Analysis of Smallholder Dairy Production Technologies in Oromiya Region, Ethiopia.

[3] Alemitu, M. (2011) Factors Affecting Adoption of Improved Haricot Bean Varieties and Associated Agronomic Practice in Dale District, SNNPS. MSc Thesis at Hawassa University, Hawassa.

[4] Alemu D., W. Mwangi, M. Nigussie, and D. J. Spielman (2008). The maize seed system in Ethiopia: challenges and opportunities in drought prone areas. African Journal of Agricultural Research, 3 (4).

[5] Asfaw S, Shiferaw B, Simtowe F, Lipper L (2012) Impact of modern agricultural technologies on smallholder welfare: Evidence from Tanzania and Ethiopia. Food Policy 37: 283295.

[6] Asfaw, S., B. Shiferaw, F. Simtowe, and M. G. Haile (2011). Agricultural technology adoption, seed access constraints and commercialization in Ethiopia. Journal of Development and Agricultural Economics. 3 (9): 436-447.

[7] Bayissa G (2014) A Double-Hurdle Approach to Modelling of Improved Teff Technologies Adoption and Intensity Use in Case of Diga District of East Wollega Zone. Global Journal of Environmental Research 8: 41-49.

[8] Chilot Yirga and RM Hassan. 2013. Determinants of inorganic fertilizer use in the mixed crop-livestock farming systems of central highlands of Ethiopia. African Crop Science Journal, Vol. 21, Issue Supplement s3, pp. $669-681$.

[9] Chilot Yirga, Dawit Alemu., Leonard Oruko, Kefyalew Negisho and Greg Taxler. 2016b. Tracking the Diffusion of Crop Varieties Using DNA Fingerprinting. Research Report 112. EIAR, Addis Ababa, Ethiopia.

[10] Chilot Yirga, Moti Jaleta, Bekele Shiferaw, Hugo de Groote, Menale Kassie, Takale Membratu and Ali Mohammad. 2013. Analysis of Adoption and Diffusion of Improved Wheat Technologies in Ethiopia. Research Report 101. EIAR, Addis Ababa, Ethiopia.

[11] Chilot Yirga, Yigezu A, and Aden Aw-Hassan. 2015a. Tracking Adoption and Diffusion of Improved Chickpea Varieties: Comparison of Approaches. Research Report 107. EIAR, Addis Ababa, Ethiopia.

[12] Chilot Yirga, Yigezu A, and Aden Aw-Hassan. $2016 \mathrm{a}$. Diffusion of Improved Lentil Varieties in Ethiopia: A Comparison of Adoption Estimates from Expert Panel, Community Focus Group Discussion and Sample Household Surveys. Research Report 113. EIAR, Addis Ababa, Ethiopia.

[13] Chilot Y and Dawit A. (2016). Adoption of Crop Technologies among Smallholder Farmers in Ethiopia: Implications for Research and Development.

[14] Croppenstedt, A., M. Demeke, and M. M Meschi (2003). Technology adoption in the presence of constraints: The case of fertilizer demand in Ethiopia. Review of Development Economics 7 (1): 58-70.

[15] CSA (Central Statistical Agency). 2014. Report on Area and Production of Major Crops (Private Peasant Holdings, Meher Season). Agricultural Sample Survey 2014/15 (2007 E. C), Volume 1. Addis Ababa, Ethiopia.

[16] Degnet A., Mekbib G. H. (2013) The impact of cooperatives on agricultural technology adoption: Empirical evidence from Ethiopia. Food Policy 38:82-91.

[17] Diiro GM (2013) Impact of Off-farm Income on Agricultural Technology Adoption Intensity and Productivity Evidence from Rural Maize Farmers in Uganda.

[18] Ermias T. Tsadik, Berhan Tamira and Zemelak Sahile (2015) Characterization of the Adoption of Village Poultry Technology Package Elements, Chicken Breeds and Forms in the Central Oromia Region, Ethiopia.

[19] FDRE. (2010). Ethiopia's Agricultural Sector Policy and Investment Framework.

[20] Feder, G. R., Just, R. E., and Zilberman, D. (1985). Adoption of agricultural innovations in developing countries: a survey. Economic Development and Cultural Change, 33, 255-298.

[21] Gebresilassie L, Bekele A (2015) Factors determining allocation of land for improved wheat variety by smallholder farmers of northern Ethiopia. Journal of Development and Agricultural Economics 7: 105-112.

[22] Hailu., Abrha, B., Weldegiorgis, K. (2014) adoption and impact of agricultural technologies on farm income: evidence from Southern Tigray, Northern Ethiopia. International Journal of Food and Agricultural Economics 2:91-106. 
[23] IFAD (2013) African agricultural development: opportunities and challenges. Statement by IFAD President at the 6th Africa Agriculture Science Week and FARA General Assembly.

[24] Kafle B (2011) Factors affecting adoption of organic vegetable farming in Chitwan District, Nepal. World Journal of Agricultural Sciences 7:604-606.

[25] Katungi E. and Akankwasa K. (2010) Community-Based Organizations and Their Effect on the Adoption of Agricultural Technologies in Uganda: a Study of Banana (Musa spp.). Pest Management Technology, National Banana Research Program, Acta Hort., 879, ISHS.

[26] Koomen, I., van Beek, C., Elias, E., Diro, M., van Kekem, A., de Roo, N., Haile, A., Asafa, B. (2015) Participatory Innovation Development: The experience of CASCAPE. In: Scaling Innovations and Agricultural Best Practices In Ethiopia. Eds. E. Elias \& C. Van Beek. Wageningen UR pp. 32 -38 .

[27] Lemma F., Trivedi M. M., Bekele T. (2012). Adoption of improved dairy husbandry practices and its relationship.

[28] Matunhu J (2011) A critique of modernization and dependency theories in Africa: Critical assessment. Afr J Hist Cult 3: 6572.

[29] Mendola M. (2007). Agricultural technology adoption and poverty reduction: A propensity-score matching analysis for rural Bangladesh, Elsevier, Food Policy 32, 372-393.

[30] Metaferia F., Cherenet, T., Gelan, A., Abnet, F., Tesfay, A., Abdi J. A., and Gulilat, W. (2011) A Review to Improve Estimation of Livestock Contribution to the National GDP. Ministry of Finance and Economic Development and Ministry of Agriculture, Addis Ababa, Ethiopia.

[31] Moshi. A., 1997. Economic impact of maize research in Tanzania. Southern African Centre for Cooperation in Agricultural and Natural Resources Research and Training: Gaborone, Botswana, pp. 15. Available at: http://libcatalog.cimmyt.org/download/cim/66519.pdf [Accessed on 11 April 2015].

[32] Ogada MJ, Mwabu G, Muchai D (2014) Farm technology adoption in Kenya: a simultaneous estimation of inorganic fertilizer and improved maize variety adoption decisions.

[33] Pretty J, Toulmin C, Williams S (2011) Sustainable intensification in African agriculture. International Journal of Agricultural Sustainability 9:5-24.

[34] Quddus M. A., (2013). Adoption of Dairy Farming technologies by Small Farm Holders: Practices and.

[35] Ray, G. L. (2001). Extension Communication and Management. Naya Prokash Publisher, Calcutta. 162pp.

[36] Rubin. D. B \& Rosenbaum P. R., (1983). The central role of the propensity scores in observational studies for causal effects, Biometika, 70, 1: 41-55.

[37] Shiferaw B, Kassie M, Jaleta M, Yirga C (2014) Adoption of improved wheat varieties and impacts on household food security in Ethiopia. Food Policy 44: 272-284.
[38] Shiferaw BA, Okello J, Reddy RV (2009) Adoption and adaptation of natural resource management innovations in smallholder agriculture: reflections on key lessons and best practices. Environment, Development and Sustainability 11: 601-619.

[39] Simegnew Tamir, Fessiha Moges, Yeshiwas Tilahun and Molla Hile (2015) Determinants of adoption of exotic poultry breeds among smallholder poultry producers in North Western Amhara Region, Ethiopia.

[40] Solomon A., Shiferaw, B., Simtowe, F., Lipper, L. (2012) Impact of modern agricultural technologies on smallholder welfare: Evidence from Tanzania and Ethiopia. Food Policy 37:283-295.

[41] Spielman, D. J., Byerlee, D., Alemu, D., Kelemework, D., 2010. Policies to promote cereal intensification in Ethiopia: The search for appropriate public and private roles. Food Policy 35, 185-194.

[42] Tamrat Gebiso (2015) adoption of modern bee hive in Arsi Zone of Oromia Region: Determinants and benefits. Oromia Agricultural Research Institute, Asella Research Center, Asella, Ethiopia. Journal of Agricultural Sciences.

[43] Tefera T, Tesfay G, Elias E, Diro M, Koomen I (2016) Drivers for adoption of agricultural technologies and practices in Ethiopia.

[44] Teklewold H, Kassie M, Shiferaw B (2013) Adoption of multiple sustainable agricultural practices in rural Ethiopia. Journal of Agricultural Economics 64: 597-623.

[45] Tewodros Tefera, Girmay Tesfay, Eyasu Elias, Mulugeta Diro, Irene Koomen (2016) Drivers for adoption of agricultural technologies and practices in Ethiopia A study report from 30 woredas in four regions.

[46] Walker T, A Alene, J Ndjeunga, R Labarta, Y Yigezu, A Diagne, $\mathrm{R}$ Andrade, $\mathrm{R}$ Muthoni Andriatsitohaina, De $\mathrm{H}$ Groote, K Mausch, Chilot Yirga, F Simtowe, E Katungi, W Jogo, M Jaleta, S Pandey, and DK Charyulu. 2015. Varietal Generation and Output. In: Walker TS and J Alwang. (Eds.). Crop Improvement, Adoption, and Impact of Improved Varieties in Food Crops in Sub-Sahara Africa. CGIAR Consortium of International Agricultural Research Centers and CAB International. ISBN-13: 9781780644011 (CABI).

[47] Wongelu Endale, 2014. Adoption of Transitional Chefeka Bee Hive Package: The Case of Wolmera Woreda, www.resjournals.org/JAFS ISSN: 2346-7002 Vol. 2 (5): 126135May, 2014.

[48] Yigezu A. Yigezu; Chilot Yirga, and Aden Aw-Hassan. 2015. Varietal Output and Adoption in Barley, Chickpea, Faba Bean, Field Pea and Lentil in Ethiopia, Eritrea and Sudan. In: Walker T. S and Alwang J. (Eds.). Crop Improvement, Adoption, and Impact of Improved Varieties in Food Crops in Sub-Sahara Africa. CGIAR Consortium of International Agricultural Research Centers and CAB International. ISBN13: 9781780644011 (CABI).

[49] Yu, B., Nin-Pratt, A., Funes, J., Asrat, S. (2010) Cereal Production and Technology in Ethiopia. IFPRI - ESSP II Discussion Paper 12. Washington, D. C.: International Food. Policy Research Institute. 